\title{
Participation in (non)violent protests and associated psychosocial factors: sociodemographic status, civic engagement, and perceptions of government's performance
}

\author{
Lu-Anne Swart ${ }^{1,2}$, Sarah Day ${ }^{1,2}$, \\ Rajen Govender ${ }^{3}$ and Mohamed Seedat ${ }^{1,2}$
}

\begin{abstract}
A national representative sample of adults is used to assess whether socioeconomic circumstances, civic engagement, and perceptions about government performance are associated with participation in (non)violent protests. Blacks and those who report high levels of poverty and civic engagement are likely to participate in non-violent protests. Individuals who have not completed schooling, are members of an organisation, view government as highly corrupt, and rate government's service delivery very unfavourably are more likely to participate in violent protests than non-violent protests. The varying paths to protests including the psychosocial factors and motivational dynamics underlying individual's participation in protests are discussed.
\end{abstract}

\section{Keywords}

Civic engagement, government performance, (non)violent protests, socioeconomic circumstances

South Africa, the 'protest capital of the world' (see Alexander, 2010), registers a high and increasing number of public protests annually. Between 1997 and 2013, police recorded 67,750 protests (Runciman et al., 2016), and media reports showed that there were 343 protests in 2015,377 protests in 2016, and 375 protests in 2017 (Runciman, 2017). Protests have also been marked by rising

\footnotetext{
'Institute for Social and Health Sciences, University of South Africa, South Africa

${ }^{2}$ Violence, Injury and Peace Research Unit, South African Medical Research Council and University of South Africa, South Africa

${ }^{3}$ Department of Sociology, University of Cape Town, South Africa
}

\section{Corresponding author:}

Lu-Anne Swart, Institute for Social and Health Sciences, University of South Africa, P.O. Box I087, Lenasia, Johannesburg 1820, South Africa.

Email: swartl@unisa.ac.za 
levels of violence, including conflict between the police and protestors, resulting in injuries, loss of life, and/or damage to property. Whereas in 2007, violence was reported in $47 \%$ of protests, by $2014,83 \%$ of protests was marked by some form of violence (Alexander, 2010; Bedasso \& Obikili, 2016; Netswera \& Kgalane, 2014; Powell et al., 2015).

A growing body of research focuses on explaining the socioeconomic and political factors, and contexts driving high levels of (non)violent protests (Alexander, 2010; Duncan, 2016; Mottair \& Bond, 2012; Paret et al., 2017; Von Holdt et al., 2011). Impoverished communities have engaged in protests to obtain basic services, such as water, electricity, sanitation, housing, education, and healthcare, as well as employment opportunities (Mottair \& Bond, 2012; Von Holdt et al., 2011). Critical sociological explanations argue that while such protests may be understood as a common form of mobilisation drawing attention to collective grievances related to unacceptable material conditions (see Runciman et al., 2016), they are actually a 'rebellion of the poor' (Alexander, 2010), reflective of insurgent citizenship, and constituting petitions for fundamental socioeconomic and political transformation, including demands by marginalised communities for inclusion in decision-making processes and structures (see Pithouse, 2007; Von Holdt et al., 2011).

Other South African studies concentrate on individual-level factors associated with protests such as 'race', socioeconomic status, gender, education, civic engagement, and perceptions of government performance (e.g., Bedasso \& Obikili, 2016; Gordon et al., 2018; Lavery, 2012). Afrobarometer data indicate that Blacks (13\%), as opposed to Whites (1\%) or 'coloureds' (8\%), report the highest level of participation in demonstrations and/or marches. 'Race' is often a proxy for income inequality (see Netswera \& Kgalane, 2014); many protests cite grievances of an economic nature (Bohler-Muller et al., 2017). While Lavery (2012) observed that there is no association between self-reports of protest participation and age or sex, others have pointed out that age, gender, and masculinity are important features of protests (see Langa \& Kiguwa, 2013; Von Holdt et al., 2011). While women are present in protests, it is mainly young men who are associated with collective violence and destruction of property (see Von Holdt et al., 2011). South Africans who have attended some university or schooling, but not completed university, have a high likelihood of having protested (Lavery, 2012). Civic engagement and negative perceptions of government performance are noted as key factors influencing individuals' participation in political gatherings, including public marches (Gordon et al., 2018).

Moving away from what appears to be binary explanations that focus on either the structural or macro-determinants or individual-level factors, our study offers a psychosocial reading of protests. After analysing and considering the individual-level factors associated with protests, we also attempt to theorise the motivational dynamics underlying protest participation and the different pathways to protests in the country. The current study specifically aims to understand how sociodemographic status, civic engagement, and views of government performance may explain (1) participation in protests compared to non-participation, and (2) the different pathways to (non)violent protests. The study is guided by two research questions: How are sociodemographic status, civic engagement, and views of government associated with protests? Is there a differential in their influence on non-violent and violent protests?

The different forms of protests we refer to here is not meant as an uncritical acceptance of the non-violent-violent protest binary. Instead, we submit that protests, incorporating material and discursive forms of resistance, are directed at disrupting asymmetrical socioeconomic, political, and cultural systems (Duncan, 2016; Quaranta, 2017; Runciman et al., 2016), and as such may include a range of disruptive repertoires (see Day et al., 2019). Protests may be enacted as normatively endorsed actions such as petitions, boycotts, demonstrations, and marches, as well as activities constituting forms of insurgency and rebellion including affective practices that may be censured by ruling institutions (see Alexander, 2010; Canham, 2018; Pithouse, 2007, 2011; Quaranta, 2017). 


\section{Explanations on protest participation: interpretive framework}

By way of situating our analysis theoretically, we begin by presenting an interpretive explanatory framework that is derived from, among others, Van Stekelenburg and Klandermans $(2013,2017)$; Canham (2018), who theorises rage as a generative force manifest in protests; and Moseley (2015), who highlights the interactive effects of weak political institutions and community engagement to explain protest participation. Van Stekelenburg and Klandermans (2013, 2017), following an extensive review of the large body of empirical and theoretical social psychology literature on protests, observe that protest participation is associated with five psychosocial factors: grievance, emotion, efficacy, social embeddedness, and collective identity.

Recognising that all these factors function interactively to influence protest participation, Van Stekelenburg and Klandermans $(2013,2017)$ and Van Stekelenburg et al. (2011) propose a motivational framework that combines identities, grievances, and emotions. They explain that grievances become a mobilising force when a group's interests and/or assumed principles are undermined or violated. As assessments of violations and threat intensify, individuals become angrier and thus more receptive to participate in group protests to express their emotions, defend their threatened interests and/or principles, and demand change collectively. Shared grievances and emotions spawn shared identity. There may be a certain circularity to this motivational dynamic. The more people identify with their group, the stronger their grievances and anger, and the more responsive they are to participate in protests on behalf of the group (Van Stekelenburg \& Klandermans, 2013, 2017).

Whereas Van Stekelenburg and Klandermans' $(2013,2017)$ motivational framework is founded mainly on studies conducted within Western democracies, Moseley (2015) explains that the trend towards increasing protests in Latin America is the outcome of the interactive effects of weak political institutions and community engagement. Higher percentages of educated, formally employed, and socially networked individuals are likely to resort to protests where government institutions are unrepresentative, weak, and ineffectual and fail to deliver on the population's aspirations for a better quality of life and expectations related to participatory democracy. In Moseley's (2015) explanation, 'community engagement' is referenced as individuals' social embeddedness and the degree to which individuals are aware of and interested in public matters and attached to community associations that may raise critical consciousness and mobilise for collective struggles. Resonant with resource-based theories, Moseley (2015) explains that it is weak institutions together with socially embedded individuals who have access to resources associated with education and networking that produce the conditions for protest action.

For Moseley, there are at least two pathways of political participation for the educated, regularly employed, and socially embedded: through formal state institutions where such institutions are functional, responsive, and able to channel people's demands for inclusion in political processes and through protests where state institutions are ineffectual and inept. However, protest participation itself does not follow a monolithic path. Van Stekelenburg and Klandermans $(2013,2017)$ explain there are two paths to protests which seem to resonate with grievance-based and resourcebased explanations, respectively. In the case of grievances around specific material interests, protests underscored by a sense of group efficacy are likely to assume an instrumental route meant to effect changes and reform around indicated grievances. The instrumentalist path seems to lead to non-violent protests. The expressive path is followed when institutionalised channels are ineffective, unrepresentative, or unresponsive. Manifest in protests that may include violence, the expressive path may see protestors focused primarily (but not exclusively) on communicating their anger and frustrations and asserting their rights to dignity, regard, and representation (see Van Stekelenburg et al., 2013). 
We extend on the preceding explanations to suggest that in South Africa protests may follow a reformist and/or insurgency path. These paths are not necessarily mutually exclusive as protestors may move in and out of them. The reformist path, akin to the instrumentalist forms of protests, are focused on specific grievances and represent demands for specific reforms as well as material resources and services. The reformist path is likely to be followed by those who have a basic or advanced level of education, who are socially embedded within consciousness-raising networks and have a firm interest in public affairs, and when individual grievances converge with group grievances and assume political significance (see Foster \& Matheson, 1999). These individuals may show a sense of group and political efficacy and believe that their collective actions can yield responses from the authorities.

The insurgency path, located within more sustained modes of struggle, brings attention to the processes and outcomes of structural violence. Within enactments of insurgent protests, the demands for basic services and material improvements (see Mottair \& Bond, 2012) are constituted as part of a long-term strategic mobilisation for participatory democracy (see Alexander, 2010; Pithouse, 2007, 2011). Within insurgent forms of protests, affect is pronounced and may function in tandem with cognitive and moral assessments of everyday realities (see Simiti, 2015; Van Zomeren, Postmes, \& Spears, 2008) to heighten awareness of systemically induced experiences of disregard and disrespect (see Canham, 2018). Shared emotional energy drives a sense of solidarity and collective action. In insurgent forms of protests, intense emotions like rage may be mobilised as a politically generative force and as part of a repertoire of affective practices to affirm the mutuality of everyday material and emotional experiences and bring public attention to hegemonic arrangements that fail to regard the humanity of the poor (see Canham, 2018; Van Stekelenburg \& Klandermans, 2013, 2017).

We also propose that these two paths may be indicative of the varying associations of political efficacy, a sense of understanding of political matters and trust in government (see Cappella \& Jamieson, 1997), and protest participation. Those with a strong sense of political efficaciousness may tend to engage in reformist modes of protests which are officially sanctioned; in contrast, people who are politically cynical - distrusting government and sceptical about the effects of normative forms of political actions - may move towards non-normative and insurgent forms of protests (see Moseley, 2015). The likelihood of politically efficacious people participating in protests is enhanced when they are located within social networks that create opportunities for political discussions, encourage interests in public affairs, raise critical consciousness about the shaping influences of socioeconomic structures on everyday realities, and offer resources in the form of skills and information to join protests (see Klandermans et al., 2008; Klandermans \& Oegema, 1987; Verba et al., 1995).

\section{Method}

\section{Participants}

The fifth round Afrobarometer 2011 survey, serving as our data source, collected nationally representative demographic and public opinion data on social, economic, and political conditions in more than 35 African countries. Although data from the most recent Afrobarometer survey (2016) in South Africa are available, this survey was unsuitable for analysis as it excluded information on the use of violence for a political cause. The 2011 barometer surveyed 2400 South African adults (aged 18 years and older) via face-to-face interviews in one of the 11 languages. Following the removal of cases with missing values for the variables under investigation, the final sample for our analysis comprised 1979 respondents. 
Table I. Cross-tabulation of items to create dependent variable $(n=1979)$.

\begin{tabular}{|c|c|c|c|}
\hline \multirow[t]{3}{*}{ Item } & & \multicolumn{2}{|c|}{ Item } \\
\hline & & \multicolumn{2}{|c|}{$\begin{array}{l}\text { I: Attended a demonstration/protest march } \\
\text { during the past year }\end{array}$} \\
\hline & & No & Yes \\
\hline \multirow{2}{*}{$\begin{array}{l}\text { 2: Used force/violence for a } \\
\text { political cause during the past year }\end{array}$} & No & I 773 (90.2\%) & I 42 (7.2\%) \\
\hline & Yes & $13(0.1 \%)$ & $51(2.6 \%)$ \\
\hline
\end{tabular}

\section{Procedure}

Two questionnaire items from the Afrobarometer, (1) attended a demonstration or protest march during the past year and (2) used force or violence for a political cause during the past year, were cross-tabulated to create the dependent variable (see Table 1). These two items formed part of a list of items in the Afrobarometer questionnaire. Participants were asked, 'Here is a list of actions that people sometimes take as citizens. For each of these, please tell me whether you, personally, have done any of these things during the past year'. The survey did not define force and violence. However, we assumed the survey referred to violence as including direct acts of physical harm, damage to property, and acts of intimidation.

Due to the small number, the 13 respondents who indicated that they never attended a protest and used force or violence during the past year were excluded from the study. The dependent variable was nominal with three categories:

- Non-participation (individuals who did not participate in a demonstration or march nor used violence for a political cause; $n=1773,90.2 \%$ );

- Participation in non-violent protests (individuals who participated in a demonstration or march but did not use violence for a political cause; $n=142,7.2 \%$ );

- Participation in violent protests (individuals who participated in a demonstration or march and used force or violence for a political cause; $n=51,2.6 \%$ ).

Eleven individual-level explanatory variables were selected from the Afrobarometer. These variables were like those used in previous national (Bedasso \& Obikili, 2016; Gordon et al., 2018; Lavery, 2012) and international (DiGrazia, 2014; Marien et al., 2010; Moseley, 2015; Stockemer, 2014) studies on individual-level factors associated with protest participation. These variables were grouped as sociodemographic, civic engagement, and assessments of government performance.

The sociodemographic variables included age, gender, race, education, and self-reported poverty. Respondents' age was measured as a continuous variable ranging from 18 to 95 years. Gender was coded as a dichotomy (male $=1$ ). Race consisted of a dichotomous variable coded as 1 if the respondent was Black ${ }^{1}$ and 0 for all other race groups. Education also measured as a dichotomous variable was coded 1 if the respondent had Grade 12 or higher, and 0 if the respondent had less than Grade 12. Poverty was measured using the Afrobarometer Lived Poverty Index (Bratton, 2006) and comprised the mean of six items: how often respondents or a family member had gone without food, water, medicines or medical treatment, fuel to cook, cash income, and/or electricity in the past year. Scores on the index ranged from never (0), just once or twice (1), several times (2), many times (3), to always (4). All the measures of poverty loaded on a single factor, with the scale demonstrating excellent reliability (Cronbach's $\alpha=.84$ ).

Two variables captured individuals' civic engagement: political interest and organisational membership. The political interest measure, based on a 4-point scale item, asked respondents how 
interested they are in public affairs. The responses ranged from not at all interested (0) to very interested (3). Organisational membership, based on a scale item, asked respondents whether they are a member of a voluntary association or community group and rated the strength of membership. The 4-point scale measuring strength of membership includes not a member (0), inactive member (1), active member (2), and an official leader (3).

Four variables measured individual's perception of government performance: government involvement in corruption, government economic performance, government service delivery performance, and assessment of local government performance. Government involvement in corruption consisted of the mean of four items that asked respondents to indicate how many government officials, local government councillors, and/or members of the Presidency and parliament are involved in corruption. The items were assessed on a 4-point scale from none (0) to all (3). A maximum likelihood factor analysis extracted a single-factor solution, accounting for $65.5 \%$ of the shared variance. The scale constituted from this single factor demonstrated excellent reliability (Cronbach's $\alpha=.82$ ).

A respondent's assessment of government's economic performance was measured using the mean of five items asking respondents how well they would say government is handling the following matters: managing the economy, improving living standards of poor, creating jobs, keeping prices down, and narrowing the gap between rich and poor. Each item is assessed on a 4-point scale from very badly (1) to very well (4). The five items loaded on a single factor, accounting for $60.0 \%$ of the shared variance with scale reliability at $\alpha=.83$.

The assessment of government service delivery consisted of the mean of six items asking the respondents how well they would say government is handling matters of improving basic health services, addressing education needs, providing water and sanitation services, maintaining roads and bridges, providing reliable supply of electricity, and distributing welfare payments. Each item was assessed on a 4-point scale: very badly (1) to very well (4). A maximum likelihood factor analysis extracted a single-factor solution $(54.5 \%$ of the shared variance) with the constituted scale of excellent reliability $(\alpha=.83)$.

Local government performance assessment was measured using the mean of five items that asked respondents how well they thought local government is handling the maintenance of local roads, marketplaces, health standards, keeping community clean, and managing land use. Each item was assessed on a 4-point scale: very badly (1) to very well (4). A maximum likelihood factor analysis extracted a single factor, accounting for $70.3 \%$ of the shared variance. The composite scale was highly reliable $(\alpha=.89)$.

Respondents were on average 39.2 years old, half (50.1\%) were male, $62.3 \%$ were Black, and $44.9 \%$ had a Grade 12 or higher level of education. Most $(70.9 \%)$ of the respondents scored between 0 and 1 on the poverty index, indicating that they or family members had gone without food, water, medicines or medical treatment, fuel to cook, cash income, and/or electricity once or twice in the year prior to the survey (see Table 2).

Civic engagement varied considerably among respondents, with $18.8 \%$ not at all interested, $24.1 \%$ not very interested, $33.6 \%$ somewhat interested, and $23.5 \%$ very interested in public affairs $(M=1.62)$. Most $(76.7 \%)$ respondents, though, were not members of a voluntary association or community group (11.4\% inactive member, $10.7 \%$ active member, 1.2 official leader) $(M=0.36)$.

Overall, respondents' assessments of government performance were negative. On average, respondents indicated that many of government officials are involved in corruption $(M=1.47)$. Of all the items measuring performance, government's economic performance received the lowest rating $(M=1.990)$, and government's service delivery performance earned the highest rating $(M=2.72)$. 
Table 2. Variable descriptive statistics $(n=1,966)$.

\begin{tabular}{lcccc}
\hline Variable & Mean/Proportion & SD & Minimum & Maximum \\
\hline Sociodemographic characteristics & & & & \\
$\quad$ Age & 39.21 & 16.06 & 18 & 95 \\
$\quad$ Gender (male) & $50.1 \%$ & & & \\
Race (Black) & $62.3 \%$ & & & \\
Education attainment (school and higher) & $44.9 \%$ & .804 & 0 & 4 \\
$\quad$ Lived Poverty Index & .746 & & & \\
Civic engagement & & 1.036 & 0 & 3 \\
$\quad$ Interest in public affairs & 1.62 & .720 & 0 & 3 \\
$\quad$ Organisational membership & 0.36 & & & \\
Assessment of government's performance & & .614 & 0 & 3 \\
$\quad$ Government involvement in corruption & 1.479 & .663 & 1 & 4 \\
$\quad$ Government's economic performance & 1.990 & .676 & 1 & 4 \\
$\quad$ Government's service delivery performance & 2.724 & .783 & 1 & 4 \\
Local government performance & 2.349 & & & \\
\hline
\end{tabular}

\section{Ethical considerations}

The study, as part of a larger project on public protests, received ethical clearance from the University of South Africa (number: 2016/CGS/35/R).

\section{Data analysis}

The dependent variable for the analysis is a nominal variable with three categories: non-participation, participation in non-violent protests, and participation in violent protests. Multinomial logistic regression was used to examine how the various individual variables may be salient for explaining participation in protests and for differentiating participation by form of protests. The modelling strategy, like that used by DiGrazia (2014) to examine differences between conventional normatively approved and non-conformist activism, allowed for the analysis of differences between non-participation and participation in non-violent protests as well as the difference between participation in non-violent and violent protests. Significance level for all analyses was set at $p=.05$. IBM SPSS Statistics for Windows, version 25.0, was used for the analyses.

\section{Results}

Table 3 displays the results of the multinomial logistic regression. The first three columns display the odds ratios (ORs), confidence intervals (CIs), and significance values for performance of the explanatory variables, differentiating between participation in non-violent protests and non-participation. The next three columns show the ORs, CIs, and significance values for performance of the explanatory variables, differentiating between participation in violent protests and non-participation. The final three columns display the ORs, CIs, and significance values for performance of the explanatory variables, differentiating between participation in violent protests and non-violent protests. All ORs presented are derived from the multivariate logistic regression and are adjusted for the effect of all other explanatory variables.

The overall logistic regression model was statistically significant $\left(\chi^{2}=237.208, p=.000\right)$, indicating that the combined effect of the explanatory variables was significant in differentiating the 
three forms of participation. The logistic regression analysis provides three estimates of pseudo- $R^{2}$, of which the most useful is the Nagelkerke estimate (see Field, 2017). Noting that the Nagelkerke estimate is .214 , the explanatory variables in combination explain approximately $21.4 \%$ of the variance of the dependent variable.

With respect to individual sociodemographic characteristics, in the context of other key variables, age and gender do not influence protest participation in any way. 'Race', on the other hand, appears to be strongly associated with participation in protest activity. Black respondents were almost three times more likely than respondents from the other 'race' groups to have participated in non-violent protests $(\mathrm{OR}=2.81, \mathrm{CI}=1.679-4.704)$ and six times more likely to have participated in violent protests $(\mathrm{OR}=6.032 ; \mathrm{CI}=1.909-19.055)$ than not to have protested at all. Respondents with higher education (completed school at least) were significantly more likely to have reported participation in non-violent protests relative to both non-participation $(\mathrm{OR}=1.653, \mathrm{CI}=1.133-2.411)$ and participation in violent protests $(\mathrm{OR}=0.341 ; \mathrm{CI}=0.159-0.729)$ (see Table 3$)$.

Although Lived Poverty Index has a positive effect on participation in non-violent and violent protests, the effect is only significant for violent protests $(\mathrm{OR}=1.399 ; \mathrm{CI}=1.012-1.935)$; respondents experiencing greater levels of poverty were more likely to report participation in violent protests compared to non-participation in protests.

Civic engagement appears to be an important influencing factor for participation in both (non) violent protests relative to non-participation, with variability across non-violent and violent protests. Interest in public affairs seems to be more strongly associated with participation in non-violent protests relative to either non-participation $(\mathrm{OR}=1.506, \mathrm{CI}=1.236-1.835)$ or participation in violent protests $(\mathrm{OR}=.693, \mathrm{CI}=0.487-0.985)$. Organisational membership has a significant positive effect for participation in both non-violent $(\mathrm{OR}=1.729, \mathrm{CI}=1.408-2.123)$ and violent $(\mathrm{OR}=2.570$, $\mathrm{CI}=1.911-3.455)$ protests; respondents who were members of an organisation were significantly more likely to have participated in non-violent protests than those who were not members. Furthermore, organisational membership appears to be more strongly associated with participation in violent protests relative to non-violent protests $(\mathrm{OR}=1.486, \mathrm{CI}=1.060-2.084)$.

Respondents rated government performance negatively across the different dimensions. Individual perceptions of government appear to be more strongly associated with participation in violent protests than non-violent protests and serve to differentiate between the two forms of protests. Perceptions of government's economic performance and perceptions of government's service delivery performance appear to influence participation in both non-violent and violent protests relative to non-participation, with the direction of the effect differing across non-violent and violent protests. Respondents who rated government's economic performance more negatively were more likely to have participated in non-violent protests than not to have participated $(\mathrm{OR}=0.718$, $\mathrm{CI}=0.524-0.983$ ), while those who rated government's economic performance less negatively were more likely to have participated in violent protests as compared to non-participation $(\mathrm{OR}=1.704$, $\mathrm{CI}=1.008-2.879)$ and participation in non-violent protests $(\mathrm{OR}=2.373, \mathrm{CI}=1.317-4.277)$. Respondents who rated government's service delivery performance less negatively were more likely to report participation in non-violent protests $(\mathrm{OR}=2.224, \mathrm{CI}=1.539-3.213)$, whereas those who rated government's service delivery more negatively were more likely to report engaging in violent protests relative to either non-participation $(\mathrm{OR}=.518, \mathrm{CI}=0.297-0.902)$ or participation in nonviolent protests $(\mathrm{OR}=.233, \mathrm{CI}=0.122-0.444)$. Respondents who perceived government as more corrupt were significantly more likely to engage in violent protests than not to have protested at all $(\mathrm{OR}=2.607, \mathrm{CI}=1.653-4.113)$ and to have protested non-violently $(\mathrm{OR}=2.170, \mathrm{CI}=1.295-3.638)$. Respondents who rated local government's performance less negatively were more likely to participate in violent protests as compared to either non-participation $(\mathrm{OR}=1.951, \mathrm{CI}=1.244-3.058)$ or participation in non-violent protests $(\mathrm{OR}=1.837, \mathrm{CI}=1.837-3.051)$. 


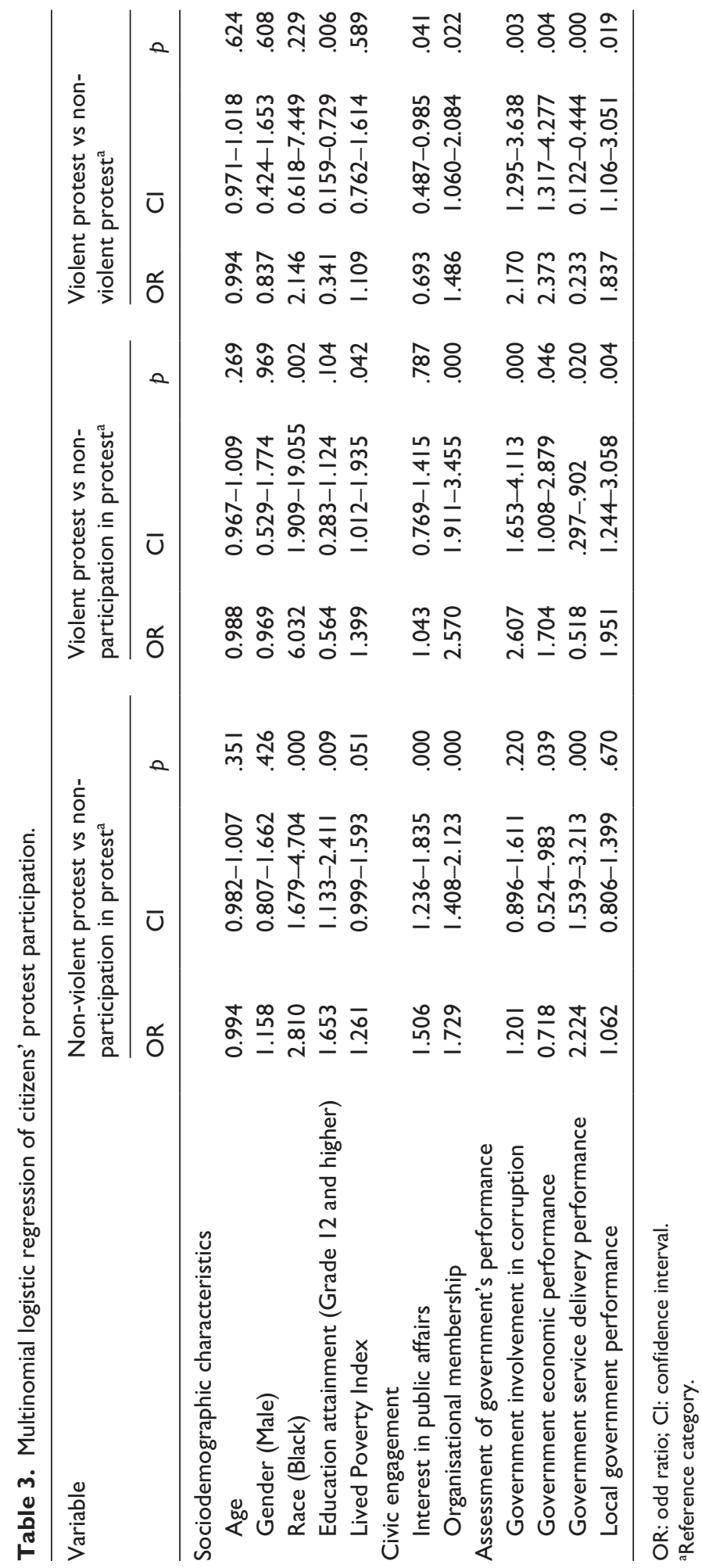




\section{Discussion}

Following the logic of motivational framework (see Van Stekelenburg \& Klanderman, 2017) and theoretical claims presented earlier, and referenced against the aims of the study, we offer an explanation - albeit speculative - of the most pertinent results below. Space constraints do not permit detailed explanations of all the results.

Compared to non-protestors, those who report participation in non-violent protests are mainly Black, more educated, experience higher levels of poverty, have greater interest in public affairs, and have higher levels of organisational membership. Though not exclusively, their main grievances centre on government's economic performance and poor local government performance. We suggest that those who participate in non-violent protests (compared to non-participation) may be enabled to do so by virtue of their relatively higher educational levels and advocacy skills that accrue from their social embeddedness. Their higher levels of education, interests in public affairs and social embeddedness that facilitate optimal access to resources, knowledge of institutional arrangements, and advocacy capital required to petition authorities in non-violent ways (see DiGrazia, 2014) may enhance their feelings of political efficacy and associated belief that pressuring state institutions non-violently (as opposed to disengagement) can yield desired reforms. They are united in collective action around a shared identity, borne out of collective grievances centred mainly on economic disparities and poor local government services within racialised geographical spaces and an embeddedness in social networks that foster critical conversations about everyday experiences and offer organisational resources for normative political engagement (see Van Stekelenburg \& Klandermans, 2013, 2017).

The respondents who reported participation in violent protests were mainly Black, did not complete formal schooling, experience very high levels of poverty, and are members of organisations. Thus, those who reported participation in violent protests (compared to non-participation) also seem to be partly motivated by united shared identity developed through mutual experiences of elevated levels of poverty and associated dissatisfactions about high levels of government corruption and poor service delivery and local government's performance, as well as through connections with organisations that may offer opportunities for resources for collective mobilisation. Although organisational membership has a significant positive effect for participation in both non-violent and violent protests, individuals who are members of an organisation are significantly more likely to participate in violent protests than non-violent protests. This suggests that engagement in organisations enables poor people who have lower levels of formal education to learn about the workings of political institutions, develop advocacy skills and counter-hegemonic consciousness, build social capital, and cultivate trust, solidarity and loyalty - all critical enablers for individual's participation in protests (Moseley, 2015; Van Stekelenburg \& Klandermans, 2013; Verba et al., 1995). It appears that within social networks, individual grievances and affect are transformed into shared grievances and shared emotions as generative and political energy (see Canham, 2018; Van Stekelenburg \& Klandermans, 2013).

The salience of 'race' (see also Bohler-Muller et al., 2017; Lavery, 2012) in (non)violent protests is unsurprising; in South Africa, the majority of Black population continues to experience high levels of poverty, unemployment, and various forms of socioeconomic inequality. Assuming 'race' as a proxy for socioeconomic disadvantage, our results may be interpreted to suggest the poor who are unified around shared grievances and ensconced within networks that offer organisational skills and catalysts for collective mobilisation engage in (non)violent protests (see Canham, 2018; Runciman, 2017; Von Holdt et al., 2011). The poor may engage in (non)violent protests in a context that is marked by weak institutional arrangements and inadequate institutional mechanisms to respond to their demands for participatory democracy and basic municipal, health, and social services (see Alexander, 2010; Von Holdt et al., 2011). 
Even though our study did not aim to analyse explicitly how the politics of reform and insurgency may influence protest participation, our results also help us observe tentatively what seems to be two different pathways to protests. Comparing factors associated with violent and non-violent protests, it appears that those who reported participation in non-violent protests may assume a reformist path that is shaped by an instrumentalist agenda and specific material interests and a primary concern with pressuring government to effect directed changes within the economy and local government services. Perhaps partly motivated by a sense of their political efficacy borne out of their relatively higher education and interests in public affairs, these individuals may assume that the reformist path is adequate to obtain responses from official institutions. We surmise that both higher levels of education and interests in public affairs offer individuals who adopt the reformist path insights into how formal institutions operate and how to leverage collective actions for purposes of effecting institutional responses.

In contrast, those who report engagement in violent protests (compared to non-violent protests) seem to adopt the insurgency path that may be exploited sometimes by 'thuggish elites' (see Von Holdt et al., 2011). Highly negative assessments of government's service delivery performance and corruption, perhaps constituting betrayal of democratic principles and failures of social justice, may produce scepticism about the utility of normative forms of political engagement and rage directed at government, especially when the government may be experienced as being repeatedly uncaring about people's basic needs for material well-being and dignity (see Canham, 2018; De Juan \& Wegner, 2019; Moseley, 2015). Those who may be united by a shared identity, perhaps created through prolonged experiences of material deprivation and psychological disregard, as well as inaccessibility to government institutions, may adopt the insurgency path, encompassing affective practices, manifest partly in violence (see Alexander, 2010; Canham, 2018).

The results of this study must be considered against the backdrop of several limitations. We only highlight three relevant ones here due to space constraints. The study is based on cross-sectional data, making it difficult to determine causal relationships between explanatory and outcome variables. The variables in our study were limited by the questions asked in the Afrobarometer survey. There has been a reported increase in the frequency of (non)violent protests since 2011 (see Alexander et al., 2018; Netswera, 2014) and a notable shift in the proportion of the population that considers violent protests objectionable (see Bohler-Muller et al., 2017); hence, it is possible that the number of South Africans who participate in (non)violent protests may have increased since 2011 and the factors driving protests might also have changed substantially.

\section{Conclusion}

Notwithstanding the limitations, our study suggests that there are varying individual motivational dynamics and pathways underlying protests. The reformist path, representing an instrumentalist approach and perhaps assumed by those who have higher levels of education and greater interests in public affairs and possibly greater confidence in state institutions, seems to concentrate on demands for economic and material reforms. The insurgency path incorporating affective repertoires, perhaps indicative of rebellion and the ethos of participatory democracy and adopted by those who may feel betrayed by high levels of government corruption and sceptical of normative forms of engagement and yet deeply socially embedded, may reflect disaffected people's demands for socioeconomic justice and substantial transformation. More research is required to understand the interplay between structural and individual-level predictors and drivers of protests, including the varying factors shaping the different pathways to (non)violent protests in South Africa. 


\section{Declaration of conflicting interests}

The authors declared no potential conflicts of interest with respect to the research, authorship, and/or publication of this article.

\section{Funding}

The authors disclosed receipt of the following financial support for the research, authorship and/or publication of this article: This project is supported by the South African Medical Research Council (Grant Number 47541) and the University of South Africa (Project Code 822500).

\section{Note}

1. The use of 'race' as an explanatory variable remains problematic and contentious in the social and health sciences. We are sceptical about essentialised notions of 'race' and so use it guardedly to bring attention to the ongoing skewed material realities associated with 'race' in a racialised and economically divided society.

\section{References}

Alexander, P. (2010). Rebellion of the poor: South Africa's service delivery protests-a preliminary analysis. Review of African Political Economy, 37(123), 25-40.

Alexander, P., Runciman, C., Ngwane, T., Moloto, B., Mokgele, K., \& Van Staden, N. (2018). Frequency and turmoil: South Africa's community protests 2005-2017. South African Crime Quarterly, 63, 27-42.

Bedasso, B. E., \& Obikili, N. (2016). A dream deferred: The microfoundations of direct political action in preand post-democratisation South Africa. The Journal of Development Studies, 52(1), 130-146. https://doi. org/10.1080/00220388.2015.1036041

Bohler-Muller, N., Roberts, B. J., Struwig, J., Gordon, S. L., Radebe, T., \& Alexander, P. (2017). Minding the Protest: Attitudes towards different forms of protest action in contemporary South Africa. South African Crime Quarterly, 62, 81-92.

Bratton, M. (2006). Poor people and democratic citizenship in Africa (Afrobarometer Working Paper No. 56). Afrobarometer.

Canham, H. (2018). Theorising community rage for decolonial action. South African Journal of Psychology, 48(3), 319-330.

Cappella, J. N., \& Jamieson, K. H. (1997). Spiral of cynicism: The press and the public good. Oxford University Press.

Day, S., Seedat, M., Cornell, J., \& Suffla, S. (2019). A multimodal reading of public protests. Environment and Planning C: Politics and Space, 37(6), 1005-1023.

De Juan, A., \& Wegner, E. (2019). Social inequality, state-centered grievances, and protest: Evidence from South Africa. Journal of Conflict Resolution, 63(1), 31-58.

DiGrazia, J. (2014). Individual protest participation in the United States: Conventional and unconventional activism. Social Science Quarterly, 95(1), 111-131.

Duncan, J. (2016). Protest nation: The right to protest in South Africa. University of KwaZulu-Natal Press.

Field, A. (2017). Discovering statistics using IBM SPSS statistics (5th revised ed.). SAGE.

Foster, M. D., \& Matheson, K. (1999). Perceiving and responding to the personal/group discrimination discrepancy. Personality and Social Psychology Bulletin, 25(10), 1319-1329.

Gordon, S., Struwig, J., Roberts, B., Mchunu, N., Mtyingizane, S., \& Radebe, T. (2018). What drives citizen participation in political gatherings in modern South Africa? A quantitative analysis of self-reported behaviour. Social Indicators Research, 141, 791-808. https://doi.org/10.1007/s11205-018-1851-1

Klandermans, B., \& Oegema, D. (1987). Potentials, networks, motivations, and barriers: Steps towards participation in social movements. American Sociological Review, 52, 519-531.

Klandermans, B., Van der Toorn, J., \& Van Stekelenburg, J. (2008). Embeddedness and identity: How immigrants turn grievances into action. American Sociological Review, 73(6), 992-1012. 
Langa, M., \& Kiguwa, P. (2013). Violent masculinities and service delivery protests in post-apartheid South Africa: A case study of two communities in Mpumalanga. Agenda, 27(1), 20-31.

Lavery, J. (2012). Protest and political participation in South Africa: Time trends and characteristics of protesters (Briefing Paper No. 102). Afrobarometer.

Marien, S., Hooghe, M., \& Quintelier, E. (2010). Inequalities in non-institutionalised forms of political participation: A multi-level analysis of 25 countries. Political Studies, 58(1), 187-213.

Moseley, M. W. (2015). Contentious engagement: Understanding protest participation in Latin American democracies. Journal of Politics in Latin America, 7(3), 3-48.

Mottair, S., \& Bond, P. (2012). The politics of discontent and social protest in Durban. Politikon, 39(3), 309-330.

Netswera, F. G. (2014). The underlying factors behind violent municipal service delivery protests in South Africa. Journal of Public Administration, 49(1), 261-273.

Netswera, F. G., \& Kgalane, S. (2014). The underlying factors behind violent municipal service delivery protests in South Africa. Journal of Public Administration, 49(1), 261-273.

Paret, M., Runciman, C., \& Sinwell, L. (Eds.). (2017). Southern resistance in critical perspective. Routledge.

Pithouse, R. (2007). The university of Abahlali baseMjondolo. Voices of Resistance from Occupied London, $2,17-20$.

Pithouse, R. (2011). The service delivery myth. Development in Focus, 1, 5-6.

Powell, D. M., O’Donovan, M., \& De Visser, J. (2015). Civic protests barometer 2007-2014. Multi-Level Government Initiative.

Quaranta, M. (2017). Protest and contentious action. In W. R. Thomspon (Ed.), Oxford research encyclopedia of politics (pp. 1-21). Oxford University Press.

Runciman, C. (2017). The 'ballot and the brick': Protest, voting and non-voting in post-apartheid South Africa. Journal of Contemporary African Studies, 34, 419-436. https://doi.org/10.1080/02589001.201 7.1287347

Runciman, C., Alexander, P., Rampedi, M., Moloto, B., Maruping, B., Khumalo, E., \& Sibanda, S. (2016). Counting police-recorded protests: Based on South African police service data (South African Research Chair in Social Change Report No. 2). https://www.uj.ac.za/faculties/humanities/csc/Documents/ Counting\%20Police-Recorded\%20Protests.pdf

Simiti, M. (2015). Rage and protest: The case of the Greek Indiginant Movement. Contention, 3(2), 33-50.

Stockemer, D. (2014). What drives unconventional political participation? A two-level study. The Social Science Journal, 51, 201-211. https://doi.org/10.1016/j.soscij.2013.10.012

Van Stekelenburg, J., \& Klandermans, B. (2013). The social psychology of protest. Current Sociology Review, 61(5-6), 886-905.

Van Stekelenburg, J., \& Klandermans, B. (2017). Individuals in movements: A social psychology of contention. In C. Roggeband \& B. Klandermans (Eds.), Handbook of social movements across disciplines (pp. 103-139). Springer.

Van Zomeren, M., Postmes, T., \& Spears, R. (2008). Toward an integrative social identity model of collective action: a quantitative research synthesis of three socio-psychological perspectives. Psychological Bulletin, 134(4), 504-535.

Verba, S., Schlozman, K. L., \& Brady, H. E. (1995). Voice and equality: Civic voluntarism in American politics. Harvard University Press.

Von Holdt, K., Langa, M., Molapo, S., Mogapi, N., Ngubeni, K., Dlamini, J., \& Kirsten, A. (2011). The smoke that calls: Insurgent citizenship, collective violence and the struggle for a place in the new South Africa. Centre for the Study of Violence and Reconciliation and Society, Work and Development Institute, University of the Witwatersrand. 